DOI

\title{
ТИРЕОЇДНИЙ СТАТУС ОРГАНІЗМУ ДІТЕЙ НА ТЛІ ДИФУЗНОГО НЕТОКСИЧНОГО ЗОБА ТА ЙОГО ВПЛИВ НА СТОМАТОЛОГІЧНУ ПАТОЛОГІЮ
}

\author{
๑О. І. Годованець
}

\section{Вищий державний навчальний заклад України «Буковинський державний медичний університет»}

РЕЗЮМЕ. У дітей при еутиреоїдному збільшенні щитоподібної залози спостерігаються зміни тиреоїдного статусу в межах референтних значень. За напрямком змін більшості показників дистиреоз характеризується зниженням функції щитоподібної залози, що може впливати на обмінні процеси в дитячому організмі, зокрема і в зубощелепній системі. Доказом цього $є$ вірогідно гірші показники інтенсивності ураження твердих тканин зубів і тканин пародонта у дітей, хворих на ДНЗ.

КЛючОВІ СЛОВА: діти, дифузний нетоксичний зоб, стоматологічні захворювання.

Вступ. Патологія ендокринної системи посідає одне з провідних місць у структурі загальної захворюваності населення. У дитячому віці спостерігається чітка динаміка до зростання кількості ендокринних захворювань з віком [2]. За даними офіційної статистики, у структурі поширеності захворювань ендокринної системи дітей та підлітків в Україні перше місце посідає дифузний зоб, на його частку припадає 56,7 \% усіх захворювань. Особливо високі показники поширеності та захворюваності на дифузний нетоксичний зоб (ДН3) реєструють серед дитячого населення ПівнічноЗахідних регіонів нашої держави $[3,4]$.

Згідно з літературними даними, поширеність ендемічного зоба серед населення, як правило, позитивно корелює із поширеністю та інтенсивністю ураження твердих тканин зубів каріозним процесом, а також із захворюваннями тканин пародонта, що пояснюється природним екологічно обумовленим фтор-йодним дефіцитом. Фундаментальні епідеміологічні дослідження з цього питання на теренах Західної України проводили Е. А. Керімов, І. П. Горзов, А. М. Політун [1].

3 огляду на вищеперераховані факти метою роботи була оцінка тиреоїдного статусу дітей, хворих на ДНЗ, та його вплив на стоматологічну патологію у віковому аспекті.

Матеріал і методи дослідження. 3 метою аналізу тиреоїдного статусу дітей проводили визначення рівня загального $\left(\mathrm{T}_{4}\right)$ і вільного тироксину $\left(\mathrm{FT}_{4}\right)$, загального трийодтироніну $\left(\mathrm{T}_{3}\right)$, тиреотропного гормону (ТТГ) у крові методом імуноферментного аналізу з використанням діагностичних наборів ELISA фірми DRG (США). Для інтегральної оцінки функціонального стану гіпофізарно-тиреоїдної системи проводили розрахунок тиреоїдних індексів: індексу периферійної інверсії $\left(\mathrm{T}_{3} / \mathrm{T}_{4}\right)$, інтегрального тиреоїдного індексу $\left(\mathrm{T}_{3}+\mathrm{T}_{4} / \mathrm{TT}\right)$ та індексів $\mathrm{TT \Gamma} / \mathrm{T}_{3}, \mathrm{TTT} / \mathrm{T}_{4}$. Перелічені вище показники досліджували у соматично здорових та хворих на ДНЗ I-ІІ ступенів дітей віком 12 та 15 років.
Стоматологічний статус дітей визначали 3 використанням загальноприйнятих індексів, рекомендованих ВООЗ. Статистичну обробку даних проводили методом варіаційної статистики з використанням критерію Стьюдента.

Результати й обговорення. Результати дослідження показали, що у всіх групах спостереження показники тиреоїдного статусу були в межах референтних значень, тобто підтверджувався еутиреоїдний стан. Однак при порівнянні результатів, одержаних у дітей, хворих на ДНЗ, із даними практично здорових дітей виявлялись коливання рівня гормонів, що свідчить про ризик виникнення порушень діяльності щитоподібної залози у майбутньому.

Середні значення рівня тиреоїдних гормонів у крові дітей груп спостереження, наведені в таблицях 1, 2, свідчать, що у всіх обстежених, хворих на дНЗ, спостерігається вірогідне збільшення рівня ТТГ, порівняно з даними контролю. Найбільше цей показник зростав у дівчаток віком 12 років: з $(1,46 \pm 0,10)$ мМО/л у групі порівняння до $(2,21 \pm 0,22)$ мМО/л у дітей на тлі тиреопатології. Можливо, це пов'язано з початком гормональної перебудови в жіночому організмі.

У дітей за ураження ДНЗ також встановлено вірогідне збільшення концентрації $\mathrm{T}_{3}$ у крові дівчаток віком 15 років та 12-річних хлопчиків. Натомість рівні загального та вільного $\mathrm{T}_{4}$ у дітей груп дослідження та контролю віком 12 років були однаковими. У старшій віковій групі $\mathrm{T}_{4}$ вірогідно знижувався як у хлопчиків $(106,32 \pm 9,89$ нмоль/л-

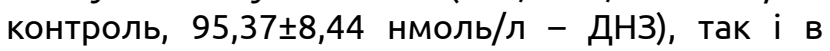

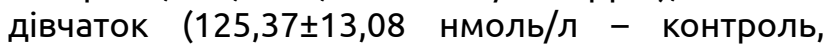
$102,91 \pm 10,53$ нмоль/л - ДНЗ). Вільна фракція гормону залишалась без змін.

Аналіз значень тиреоїдних індексів показав, що у дівчаток у випадку ДНЗ реєструються більш виражені зміни функціонального статусу гіпофізарно-тиреоїдної системи, аніж у хлопчиків. Про це свідчать такі дані: зниження на 35 \% у 
Огляди літератури, оригінальні дослідження, погляд на проблему

12-річних та на 45 \% у 15-річних дівчат інтегрального тиреоїдного індексу, на фоні зростання індексу периферійної інверсії майже удвічі у підлітковому віці та на 42 \% індексу ТТГ/ТЗ у молодшій віковій групі, порівняно з групою контролю.
Гормональний профіль у хлопчиків при супутньому ДНЗ характеризується зниженням інтегрального тиреоїдного індексу на $25 \%$ у віці 12 років та на $31 \%$ у віці 15 років при збереженні на рівні контролю інших тиреоїдних індексів.

Таблиця 1. Показники тиреоїдного статусу дітей віком 12 років із дН3 $(\mathrm{M} \pm \mathrm{m})$

\begin{tabular}{|c|c|c|c|c|c|c|}
\hline \multirow{2}{*}{$\begin{array}{c}\text { Рівень } \\
\text { гормонів }\end{array}$} & \multicolumn{2}{|c|}{ Хлопці } & \multicolumn{2}{|c|}{ Дівчата } & \multirow[b]{2}{*}{$\mathrm{P}_{1}$} & \multirow[b]{2}{*}{$\mathrm{P}_{2}$} \\
\hline & $\begin{array}{c}\text { здорові } \\
(n=25)\end{array}$ & $\begin{array}{l}3 \text { ДНЗ } \\
(n=34)\end{array}$ & $\begin{array}{c}\text { здорові } \\
(n=25)\end{array}$ & $\begin{array}{l}3 \text { ДНЗ } \\
(n=32) \\
\end{array}$ & & \\
\hline ТТГ (мМО/л) & $1,52 \pm 0,12$ & $1,97 \pm 0,20 *$ & $1,46 \pm 0,10$ & $2,21 \pm 0,22^{*}$ & $>0,05$ & $>0,05$ \\
\hline $\begin{array}{c}\mathrm{T}_{4} \\
\text { (нмоль/л) }\end{array}$ & $115,87 \pm 8,23$ & $111,05 \pm 9,46$ & $108,41 \pm 10,78$ & $105,64 \pm 7,33$ & $>0,05$ & $>0,05$ \\
\hline $\begin{array}{c}\mathrm{FT}_{4} \\
\text { (пмоль/л) }\end{array}$ & $16,12 \pm 1,34$ & $15,89 \pm 1,25$ & $14,56 \pm 1,45$ & $15,83 \pm 1,38$ & $>0,05$ & $>0,05$ \\
\hline $\begin{array}{c}\mathrm{T}_{3} \\
\text { (нмоль/л) }\end{array}$ & $2,89 \pm 0,16$ & $3,54 \pm 0,25 *$ & $2,56 \pm 0,20$ & $2,71 \pm 0,18$ & $>0,05$ & $<0,05$ \\
\hline $\mathrm{T}_{3}+\mathrm{T}_{4} / \mathrm{TT \Gamma}$ & $76,13 \pm 5,43$ & $57,16 \pm 4,32 *$ & $75,23 \pm 4,15$ & $51,03 \pm 2,35^{*}$ & $>0,05$ & $>0,05$ \\
\hline $\mathrm{T}_{3} / \mathrm{T}_{4}$ & $0,024 \pm 0,002$ & $0,031 \pm 0,002$ & $0,025 \pm 0,001$ & $0,026 \pm 0,003$ & $>0,05$ & $>0,05$ \\
\hline $\mathrm{TT} \Gamma / \mathrm{T}_{3}$ & $0,49 \pm 0,05$ & $0,58 \pm 0,04$ & $0,55 \pm 0,04$ & $0,79 \pm 0,06^{*}$ & $>0,05$ & $<0,01$ \\
\hline $\mathrm{TT} \Gamma / \mathrm{T}_{4}$ & $0,012 \pm 0,001$ & $0,018 \pm 0,002$ & $0,013 \pm 0,001$ & $0,021 \pm 0,002$ & $>0,05$ & $>0,05$ \\
\hline
\end{tabular}

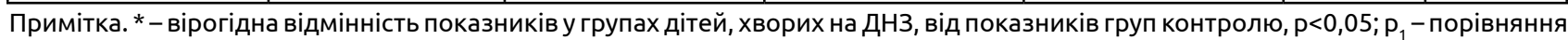
показників у здорових хлопчиків і дівчаток; $\mathrm{P}_{2}$-порівняння показників у хлопчиків і дівчаток, хворих на ДН3.

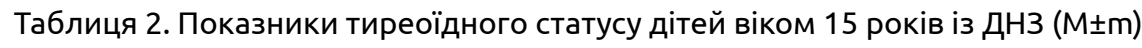

\begin{tabular}{|c|c|c|c|c|c|c|}
\hline \multirow{2}{*}{$\begin{array}{l}\text { Рівень } \\
\text { гормонів }\end{array}$} & \multicolumn{2}{|c|}{ Хлопці } & \multicolumn{2}{|c|}{ Дівчата } & \multirow[b]{2}{*}{$\mathrm{P}_{1}$} & \multirow[b]{2}{*}{$\mathrm{P}_{2}$} \\
\hline & $\begin{array}{c}\text { здорові } \\
(n=25)\end{array}$ & $\begin{array}{l}3 \text { ДНЗ } \\
(n=30)\end{array}$ & $\begin{array}{c}\text { здорові } \\
(n=25)\end{array}$ & $\begin{array}{l}3 \text { ДНЗ } \\
(n=33)\end{array}$ & & \\
\hline ТТГ (мМО/л) & $1,41 \pm 0,11$ & $1,86 \pm 0,20^{*}$ & $1,39 \pm 0,15$ & $2,09 \pm 0,30 *$ & $>0,05$ & $>0,05$ \\
\hline $\begin{array}{c}\mathrm{T}_{4} \\
\text { (нмоль/л) }\end{array}$ & $106,32 \pm 9,89$ & $95,37 \pm 8,44^{*}$ & $125,37 \pm 13,08$ & $102,91 \pm 10,53 *$ & $<0,01$ & $>0,05$ \\
\hline $\begin{array}{c}\mathrm{FT}_{4} \\
\text { (пмоль/л) }\end{array}$ & $15,04 \pm 1,47$ & $16,64 \pm 1,52$ & $17,25 \pm 1,33$ & $18,43 \pm 1,54$ & $>0,05$ & $<0,05$ \\
\hline $\begin{array}{c}\mathrm{T}_{3} \\
\text { (нмоль/л) }\end{array}$ & $3,22 \pm 0,34$ & $3,87 \pm 0,26$ & $2,43 \pm 0,21$ & $3,38 \pm 0,27 *$ & $<0,05$ & $>0,05$ \\
\hline $\mathrm{T}_{3}+\mathrm{T}_{4} / \mathrm{TT \Gamma}$ & $81,69 \pm 7,12$ & $52,35 \pm 4,84^{*}$ & $92,94 \pm 6,25$ & $51,85 \pm 4,35^{*}$ & $<0,05$ & $>0,05$ \\
\hline $\mathrm{T}_{3} / \mathrm{T}_{4}$ & $0,034 \pm 0,004$ & $0,042 \pm 0,003$ & $0,018 \pm 0,002$ & $0,035 \pm 0,003 *$ & $<0,05$ & $>0,05$ \\
\hline $\mathrm{TT} \Gamma / \mathrm{T}_{3}$ & $0,43 \pm 0,04$ & $0,48 \pm 0,03$ & $0,57 \pm 0,05$ & $0,63 \pm 0,05$ & $<0,05$ & $<0,05$ \\
\hline $\mathrm{TT} \Gamma / \mathrm{T}_{4}$ & $0,013 \pm 0,002$ & $0,019 \pm 0,002$ & $0,011 \pm 0,001$ & $0,022 \pm 0,003$ & $>0,05$ & $>0,05$ \\
\hline
\end{tabular}

Примітка. * - вірогідна відмінність показників у групах дітей, хворих на ДН3, від показників груп контролю, $><0,05 ; \mathrm{p}_{1}-$ порівняння показників у здорових хлопчиків і дівчаток; $\mathrm{P}_{2}$ - порівняння показників у хлопчиків і дівчаток, хворих на ДНЗ.

Встановлені факти свідчать про розвиток дистиреозу в дітей на тлі гіперплазії щитоподібної залози та вказують на необхідність саплементації йоду для забезпечення нормального тиреоїдного гормоногенезу.

Слід зазначити, що у групах порівняння також спостерігалась зміна досліджуваних параметрів як за віковою, так і за статевою ознаками. Зокрема, у хлопчиків на початку пубертатного періоду реєструвались вірогідно вищі показники $\mathrm{T}_{4}((115,87 \pm 8,23)$ нмоль/л) ( $<<0,05)$, аніж наприкін-

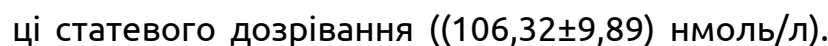
Дещо більшими за значеннями були в них також рівні ТТГ та $\mathrm{FT}_{4}$, хоча вірогідної різниці між даними показниками ми не встановили $(p>0,05)$.

У дівчаток-підлітків із збільшенням віку рівень $\mathrm{T}_{4}$ та $\mathrm{FT}_{4}$, навпаки, збільшувався на $16-18 \%$ $(p<0,05)$. За іншими показниками у осіб жіночої статі відмінностей у віковому аспекті не виявлено.

При порівнянні рівня тиреоїдних гормонів у крові хлопчиків та дівчаток в межах одних вікових груп встановлено вірогідні відмінності між рівня- 
Огляди літератури, оригінальні дослідження, погляд на проблему

ми $\mathrm{T}_{3}$ та $\mathrm{T}_{4}$ у обстежених старшого віку $(p<0,05)$. у 12-річних дітей усі досліджувані показники не мали особливостей за статтю.

Таким чином, у здорових дітей протягом пубертатного періоду спостерігається тиреоїдний дисгормоногенез із ознаками статевого диморфізму. Однак, на відміну від дітей, хворих на дНЗ, зміни гормонального статусу в них менш значимі.
Щодо стоматологічного стану здоров'я дітей груп спостереження (табл. 3, 4) слід зазначити, що показники інтенсивності карієсу зубів у дітей, хворих на ДНЗ, мали тенденцію до зростання із збільшенням ступеня тяжкості соматичної патології, що підтверджувалось вірогідною відмінністю більшості даних із групою контролю.

Таблиця 3. Показники інтенсивності карієсу зубів у дітей віком 12 років, $\mathrm{M \pm m}$

\begin{tabular}{|c|c|c|c|c|c|}
\hline \multirow{2}{*}{$\begin{array}{c}\text { Групи } \\
\text { спостереження }\end{array}$} & \multirow{2}{*}{$\begin{array}{c}\text { Підгрупи за } \\
\text { статтю }\end{array}$} & \multirow{2}{*}{$\begin{array}{l}\text { Інтенсивність } \\
\text { карієсу, КПВ }\end{array}$} & \multicolumn{3}{|c|}{$\mathrm{K}$} \\
\hline & & & $\mathrm{K}$ & $\Pi$ & $B$ \\
\hline \multirow{3}{*}{ Контроль } & разом & $2,83 \pm 0,14$ & $1,45 \pm 0,05$ & $1,34 \pm 0,11$ & $0,04 \pm 0,002$ \\
\hline & хлопчики & $2,64 \pm 0,15$ & $1,36 \pm 0,09$ & $1,25 \pm 0,09$ & $0,03 \pm 0,001$ \\
\hline & дівчатка & $3,02 \pm 0,20$ & $1,54 \pm 0,12$ & $1,43 \pm 0,13$ & $0,05 \pm 0,005$ \\
\hline \multirow{3}{*}{ ДНЗ la } & разом & $3,05 \pm 0,19$ & $1,62 \pm 0,14$ & $1,35 \pm 0,12$ & $0,08 \pm 0,009$ \\
\hline & хлопчики & $2,87 \pm 0,11$ & $1,53 \pm 0,11$ & $1,27 \pm 0,09$ & $0,07 \pm 0,007$ \\
\hline & дівчатка & $3,23 \pm 0,31$ & $1,71 \pm 0,16$ & $1,43 \pm 0,15$ & $0,09 \pm 0,005$ \\
\hline \multirow{3}{*}{ ДНЗ І6 } & разом & $3,48 \pm 0,25^{*}$ & $1,92 \pm 0,20$ & $1,42 \pm 0,08$ & $0,14 \pm 0,02 *$ \\
\hline & хлопчики & $3,28 \pm 0,15^{*}$ & $1,83 \pm 0,17$ & $1,36 \pm 0,12$ & $0,09 \pm 0,01$ \\
\hline & дівчатка & $3,69 \pm 0,20 *$ & $2,01 \pm 0,16^{*}$ & $1,48 \pm 0,11$ & $0,20 \pm 0,008 *$ \\
\hline \multirow{3}{*}{ ДНЗ ІІ } & разом & $4,58 \pm 0,37 *$ & $2,01 \pm 0,38^{*}$ & $2,06 \pm 0,17^{*}$ & $0,51 \pm 0,03 *$ \\
\hline & хлопчики & $4,43 \pm 0,25 *$ & $1,89 \pm 0,15^{*}$ & $1,97 \pm 0,13^{*}$ & $0,57 \pm 0,05^{*}$ \\
\hline & дівчатка & $4,73 \pm 0,51 *$ & $2,13 \pm 0,17^{*}$ & $2,15 \pm 0,20 *$ & $0,45 \pm 0,01$ * \\
\hline
\end{tabular}

Примітка. * - вірогідна відмінність показників від показників групи контролю, р<0,05.

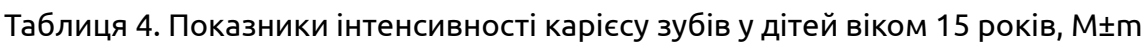

\begin{tabular}{|c|c|c|c|c|c|}
\hline \multirow{2}{*}{$\begin{array}{c}\text { Групи } \\
\text { спостереження }\end{array}$} & \multirow{2}{*}{$\begin{array}{c}\text { Підгрупи за } \\
\text { статтю }\end{array}$} & \multirow{2}{*}{$\begin{array}{l}\text { Інтенсивність } \\
\text { карієсу, КПВ }\end{array}$} & \multicolumn{3}{|c|}{$\mathrm{K}_{3}$} \\
\hline & & & $\mathrm{K}$ & $\Pi$ & B \\
\hline \multirow{3}{*}{ Контроль } & разом & $4,95 \pm 0,23$ & $2,97 \pm 0,20$ & $1,83 \pm 0,12$ & $0,15 \pm 0,01$ \\
\hline & хлопчики & $4,89 \pm 0,25$ & $3,08 \pm 0,33$ & $1,65 \pm 0,02$ & $0,16 \pm 0,02$ \\
\hline & дівчатка & $5,01 \pm 0,20$ & $2,86 \pm 0,15$ & $2,01 \pm 0,01$ & $0,14 \pm 0,01$ \\
\hline \multirow{3}{*}{ ДНЗ Іа } & разом & $6,28 \pm 0,41^{*}$ & $3,87 \pm 0,25^{*}$ & $2,13 \pm 0,18$ & $0,28 \pm 0,01$ \\
\hline & хлопчики & $6,34 \pm 0,52^{*}$ & $3,64 \pm 0,32$ & $2,45 \pm 0,20 *$ & $0,25 \pm 0,03$ \\
\hline & дівчатка & $6,22 \pm 0,48^{*}$ & $4,10 \pm 0,15^{*}$ & $1,81 \pm 0,16$ & $0,31 \pm 0,02 *$ \\
\hline \multirow{3}{*}{ ДНЗ І6 } & разом & $7,03 \pm 0,54^{*}$ & $4,28 \pm 0,30 *$ & $2,43 \pm 0,15$ & $0,32 \pm 0,01^{*}$ \\
\hline & хлопчики & $7,13 \pm 0,25^{*}$ & $4,49 \pm 0,35^{*}$ & $2,29 \pm 0,31$ & $0,35 \pm 0,02 *$ \\
\hline & дівчатка & $6,93 \pm 0,56^{*}$ & $4,07 \pm 0,28^{*}$ & $2,57 \pm 0,24$ & $0,29 \pm 0,01$ \\
\hline \multirow{3}{*}{ ДНЗ ІІ } & разом & $7,51 \pm 0,63^{*}$ & $4,58 \pm 0,20 *$ & $2,35 \pm 0,17^{*}$ & $0,58 \pm 0,05^{*}$ \\
\hline & хлопчики & $7,52 \pm 0,51$ * & $4,64 \pm 0,51^{*}$ & $2,34 \pm 0,25^{*}$ & $0,54 \pm 0,04 *$ \\
\hline & дівчатка & $7,50 \pm 0,45^{*}$ & $4,52 \pm 0,15^{*}$ & $2,36 \pm 0,24$ & $0,62 \pm 0,05^{*}$ \\
\hline
\end{tabular}

Примітка. * - вірогідна відмінність показників від показників групи контролю, p<0,05.

Аналіз інтенсивності каріозного процесу за статтю не встановив різниці в даних показниках у хлопчиків та дівчаток. Лише у дівчаток віком 12 років були дещо більші значення індексу КПВ, аніж у хлопчиків, хоча вірогідної відмінності між усіма досліджуваними критеріями не було. Така тенденція, найімовірніше, пояснюється початком швидкого морфофункціонального розвитку жіночого організму у віці 12 років, зокрема статевого дозрівання, що переводить процес вторинної мінералізації твердих тканин зубів у стан функціо- нального напруження. Зниження надходження кальцію до емалі сприяє розвитку каріозного процесу, а отже підвищує поширеність та інтенсивність карієсу в даної групи дітей.

Оцінка стану тканин пародонта за основними його симптомами ураження в дітей - кровоточивістю та зубним каменем - наведена в таблиці 5.

Поширеність пародонтопатій при ДНЗ за ознакою кровоточивості $\epsilon$ високою в обох вікових групах та вірогідно вищою, аніж у соматично здорових дітей $(p<0,05)$. За частотою виявлення твер- 
Огляди літератури, оригінальні дослідження, погляд на проблему

Таблиця 5. Показники поширеності кровоточивості та зубного каменю в дітей груп спостереження

\begin{tabular}{|c|c|c|c|}
\hline Вік дітей & Група & Кровоточивість, \% & Зубний камінь, \% \\
\hline \multirow[t]{5}{*}{12 років } & Контроль & 48,0 & 18,0 \\
\hline & ДН3 & 77,33 * & 37,33 * \\
\hline & ДН3 Ia & 72,0 * & 30,0 * \\
\hline & ДНЗ І6 & 76,0 * & 36,0 * \\
\hline & ДНЗ ІІ & 84,0 * & 46,0 * \\
\hline \multirow[t]{5}{*}{15 років } & Контроль & 70,0 & 48,0 \\
\hline & ДНЗ & $95,86 *$ & 72,41 * \\
\hline & ДН3 la & 90,0 * & $64,0 \%$ * \\
\hline & ДН3 І6 & 98,0 * & 70,0 * \\
\hline & ДНЗ ІІ & $100 *$ & 84,44 * \\
\hline
\end{tabular}

Примітка. * - вірогідна відмінність показників від показників груп контролю, р<0,05.

дих зубних відкладень спостерігається низький рівень захворювань тканин пародонта в дітей груп контролю та дітей віком 12 років, хворих на ДНЗ. У підлітків даний показник був на рівні середнього. Такі ж результати були одержані при вивченні інтенсивності ураження тканин пародонта.

Висновки. У дітей на тлі еутиреоїдного збільшення щитоподібної залози спостерігаються зміни тиреоїдного статусу в межах референтних значень. За напрямком змін більшості показників дистиреоз характеризується зниженням функції щитоподібної залози, що може впливати на обмінні процеси в дитячому організмі, зокрема і зубощелепної системи. Доказом цього $є$ вірогідно гірші показники інтенсивності ураження твердих тканин зубів і тканин пародонта у дітей, хворих на ДНЗ.

Перспективи подальших досліджень. Подальшого вивчення потребують питання впливу тиреоїдного дисгормоногенезу на розвиток стоматологічної патології в дітей та шляхи їх корекції.

\section{ЛІТЕРАТУРА}

1. Горзов І. П. Екологічні аспекти карієсу зубів та хвороб пародонту / І. П. Горзов, А. М. Потапчук. -Ужгород : ВАТ «Патент», 1998.- 225 с.

2. Дудіна О. О. Ситуаційний аналіз стану здоров'я дитячого населення / О.О.Дудіна, А. В. Терещенко // Вісник соціальної гігієни та організації охорони здоров'я України. - 2014. - № 2. - С. 49-57.

3. Зелінська Н. Б. Стан надання медичної допомоги

дітям з ендокринною патологією в Україні у 2014 році / Н. Б. Зелінська, Н. Г. Руденко // Український журнал дитячої ендокринології. - 2015. - № 2. - С. 5-13.

4. Марущак М. І. Динаміка захворюваності на ендокринопатії серед дитячого населення Тернопільської області / М. І. Марущак, Л. П. Мазур, О.В.Денефіль // Актуальні питання педіатрії, акушерства та гінекології. 2014. - № 2. - С. 62-65.

\section{THYROID STATUS OF THE CHILD'S ORGANISM AGAINST DIFFUSE NONTOXIC GOITER AND ITS EFFECT ON DENTAL PATHOLOGY}

๑O. I. Hodovanets

Higher State Educational Establishment of Ukraine «Bukovynian State Medical University»

SUMMARY. In children with euthyroiden largement of the thyroid gland there are changes of the thyroid status within referential meanings. According to the direction of changes of the most indices thyroid dysfunction is characterized by hypo function of the thyroid gland that can affect on metabolic processes in the child's organism, and the dento-alveolar system in particular. Its evidence is reliably worse indices of the intensity of affliction of the hard dental tissues and periodontal tissues in children suffering from diffuse nontoxic goiter.

KEY WORDS: children, diffuse nontoxic goiter, dental diseases. 